\title{
Article \\ Sterols and Triterpenes from Dobera glabra Growing in Saudi Arabia and Their Cytotoxic Activity
}

\author{
Wael M. Abdel-Mageed ${ }^{1,2}{ }^{\circledR}$, Ali A. El-Gamal ${ }^{1,3, *}$, Shaza M. Al-Massarani ${ }^{1}{ }^{\circledR}$, Omer A. Basudan ${ }^{1}$, \\ Farid A. Badria ${ }^{3}{ }^{(0}$, Maged S. Abdel-Kader ${ }^{4,5}{ }^{(\mathbb{C}}$, Adnan J. Al-Rehaily ${ }^{1}$ and Hanan Y. Aati ${ }^{1}$ \\ 1 Department of Pharmacognosy, College of Pharmacy, King Saud University, P.O. Box 2457, \\ Riyadh 11451, Saudi Arabia; wabdelmageed@ksu.edu.sa (W.M.A.-M.); salmassarani@ksu.edu.sa (S.M.A.-M.); \\ basudan@ksu.edu.sa (O.A.B.); ajhmkl@hotmail.com (A.J.A.-R.); hati@ksu.edu.sa (H.Y.A.) \\ 2 Pharmacognosy Department, Faculty of Pharmacy, Assiut University, Assiut 71526, Egypt \\ 3 Department of Pharmacognosy, Faculty of Pharmacy, Mansoura University, El-Mansoura 35516, Egypt; \\ faridbadria@gmail.com \\ 4 Pharmacognosy Department, College of Pharmacy, Sattam Bin Abdulaziz University, \\ Al-kharj 11942, Saudi Arabia; mpharm101@hotmail.com \\ 5 Department of Pharmacognosy, College of Pharmacy, Alexandria University, Alexandria 21215, Egypt \\ * Correspondence: aelgamel@ksu.edu.sa; Tel.: +00-9665-6978-0176
}

check for updates

Citation: Abdel-Mageed, W.M.; El-Gamal, A.A.; Al-Massarani, S.M.; Basudan, O.A.; Badria, F.A.; Abdel-Kader, M.S.; Al-Rehaily, A.J.; Aati, H.Y. Sterols and Triterpenes from Dobera glabra Growing in Saudi Arabia and Their Cytotoxic Activity. Plants 2021, 10, 119. https://doi. org/10.3390/plants10010119

Received: 26 November 2020 Accepted: 4 January 2021 Published: 8 January 2021

Publisher's Note: MDPI stays neutral with regard to jurisdictional clai$\mathrm{ms}$ in published maps and institutional affiliations.

Copyright: (C) 2021 by the authors. Licensee MDPI, Basel, Switzerland. This article is an open access article distributed under the terms and conditions of the Creative Commons Attribution (CC BY) license (https:// creativecommons.org/licenses/by/ $4.0 /)$.

\begin{abstract}
A new lupane caffeoyl ester, lup-20(29)-ene 3 $\beta$-caffeate-30-al (7), and a new oleanane-type triterpene, $3 \beta$-hydroxyolean-13(18)-en-12-one (17), were isolated from the aerial parts of Dobera glabra (Forssk), along with ten known triterpenes, including seven lupane-type lupeol (1), 30-norlup-3 $\beta$-ol-20-one (2), $\Delta^{1}$-lupenone (3), lup-20(29)-en-3 $\beta, 30$-diol (4), lupeol caffeate (5), 30-hydroxy lup-20(29)-ene $3 \beta$-caffeate (6), and betunaldehyde (8); three oleanane-type compounds were also identified, comprising $\delta$-amyrone (15), $\delta$-amyrin (16), and 11-oxo- $\beta$-amyrin (18); together with six sterols, comprising $\beta$-sitosterol (9), stigmasterol (10), $7 \alpha$-hydroxy- $\beta$-sitosterol (11), $7 \alpha$-hydroxystigmasterol (12), 7-keto- $\beta$-sitosterol (13), and 7-keto-stigmasterol (14). Their structures were elucidated using a variety of spectroscopic techniques, including $1 \mathrm{D}\left({ }^{1} \mathrm{H},{ }^{13} \mathrm{C}\right.$, and DEPT-135 $\left.{ }^{13} \mathrm{C}\right)$ and 2D $\left({ }^{1} \mathrm{H}-{ }^{1} \mathrm{H}\right.$ COSY, ${ }^{1} \mathrm{H}-{ }^{13} \mathrm{C}$ HSQC, and ${ }^{1} \mathrm{H}-13$ C HMBC) nuclear magnetic resonance (NMR) and accurate mass spectroscopy. Subsequently, the different plant extracts and some of the isolated compounds (1-9, 11 and 13) were investigated for their possible cytotoxic activity in comparison to cisplatin against a wide array of aggressive cancer cell lines, such as colorectal cancer (HCT-116), hepatocellular carcinoma (HepG-2), and prostate cancer (PC-3) cell lines. Compound 11 displayed broad cytotoxicity against all of the tested cell lines ( $\mathrm{IC}_{50} \cong 8 \mu \mathrm{g} / \mathrm{mL}$ in all cases), and a high safety margin against normal Vero cells $\left(\mathrm{IC}_{50}=70 \mu \mathrm{g} / \mathrm{mL}\right)$, suggesting that $\mathbf{1 1}$ may be a highly selective and effective anticancer agent candidate. Notably, the evidence indicated that the mode of action of compound $\mathbf{1 1}$ could possibly consist of the inhibition of phosphodiesterase I ( $80.2 \%$ enzyme inhibition observed at $2 \mu \mathrm{M}$ compound concentration).
\end{abstract}

Keywords: Dobera glabra; salvadoraceae; triterpenes; steroids; cytotoxic activity; phosphodiesterase inhibition

\section{Introduction}

The Salvadoraceae plant family comprises three genera-Azima, Dobera, and Salvadora-with around twelve species, distributed in the hot and dry areas of mostly mainland Africa, Madagascar, Southeast Asia, the Indonesian island of Java, and Malaysia [1,2]. The Salvadoraceae family is represented in Saudi Arabia by two genera: Dobera and Salvadora; both are dominant near the foothills, where Wadi Jizan originate.

Dobera is a small genus comprising only two species, Dobera loranthifolia and Dobera glabra, which are endemic to East Africa and North West India. D. glabra (Forssk) is native to many African countries, such as Djibouti, Ethiopia, Somalia, and Sudan, but it is also 
found in India and Saudi Arabia. It is a highly valued plant, and it is the only Dobera species to be found in Saudi Arabia, usually in alluvial areas, on slopes, or in Wadis like Wadi Tashar and Wadi Kawbah, in the regions near the border with Yemen [3]. This plant species might be endangered, as the local people declared that there is no new generation of the trees, and only the old trees are sparingly distributed; in a comparatively recent study, the survival rate of seedlings and samplings was observed to be greatly decreasing, and the rate of fruit production was observed to be minimal [4]. D. glabra, known as Dobar in Arabic, is a fair-sized evergreen shrub or tree with thick, leathery, opposite leaves, sweetscented white flowers, and purple ovate fruits with a layer of jelly-like edible fluid around a single flat seed. The fruits are characterized by a bad smell, and they are considered, together with the seeds, typical famine food consumed during times of drought in Ethiopia and many other African countries $[5,6]$. However, excessive ingestion causes stomach aches and intestinal problems [7]. Notably, the tree is highly valued in folkloric medicine, since its latex is applied to both eyes once daily for three days for the treatment of ophthalmic problems [8], whereas the plant's flowers provide an essential oil used as perfume [9]. In Somalia, it is mainly used as shade for the farmer and his livestock. Its bush fallow is often used to maintain soil fertility [10], and in Kenya, it is used as a diet and fodder tree [11].

Despite the importance of D. glabra as an edible plant for humans and animals, our literature search revealed only one phytochemical study conducted on this plant; it reported the isolation of seven flavonoids from the leaves of $D$. glabra, which displayed antioxidant activity and genotoxic protection against $\mathrm{CCl}_{4}$-induced liver damage in male rats [12].

Cancer is a major public health problem worldwide and is the second leading cause of death in the United States. As part of our intensive search for new bioactive compounds in Saudi plants with a potential cytotoxic activity, in the current study we thoroughly investigated D. glabra grown in the wild in Saudi Arabia in order to identify its active constituents and assess their cytotoxic activity. All of the obtained fractions, as well as some of the isolated compounds chosen based on their availability and the reported activity of structurally-related steroids and triterpenes, were screened for cytotoxic activity $[13,14]$. The biologically-guided fractionations of the different active fractions were subjected to further chromatographic isolation and separation.

\section{Results and Discussion}

\subsection{Structure Elucidation of the New Triterpenoids}

The investigation of the phytochemicals isolated from the aerial parts of D. glabra via a combination of different chromatographic methods led to the isolation of 18 triterpene and steroid compounds (1-18) (Figure 1). Two of the isolated compounds (7 and 17) are hereby reported for the first time as being isolated from a natural source, whereas the remaining compounds are hereby reported for the first time as being isolated from D. glabra [12]. The structures of the isolated compounds were elucidated via the extensive use of various spectroscopic techniques, including $1 \mathrm{D}\left({ }^{1} \mathrm{H},{ }^{13} \mathrm{C}\right.$, and DEPT- $\left.135{ }^{13} \mathrm{C}\right)$ and $2 \mathrm{D}\left({ }^{1} \mathrm{H}-{ }^{1} \mathrm{H}\right.$ COSY, ${ }^{1} \mathrm{H}-{ }^{13} \mathrm{C}$ HSQC, and ${ }^{1} \mathrm{H}-{ }^{13} \mathrm{C}$ HMBC) nuclear magnetic resonance (NMR) (Figures S1-S46) and accurate mass measurements, as well as by comparing the compounds' physical and spectral characteristics with those reported in the literature for previously-isolated compounds. The known compounds were identified as lupeol (1) [15-17], 30-norlup$3 \beta$-ol-20-one (2) [18], $\Delta^{1}$-lupenone (glochidone) (3) [19], lup-20(29)-ene-3 $\beta, 30$-diol (29hydroxylupeol) (4) [20], lupeol caffeate (5) [17,21], 30-hydroxy lup-20(29)-ene $3 \beta$-caffeate (6) [22] and betunaldehyde (8) [23]; three oleanane-type compounds were also identified: $\delta$ amyrone (15) [24], $\delta$-amyrin (16) [24], and 11-oxo- $\beta$-amyrin (18) [25]; in addition, six sterols were identified: $\beta$-sitosterol (9) [26], stigmasterol (10) [27], $7 \alpha$-hydroxy- $\beta$-sitosterol (11) [28], $7 \alpha$-hydroxy-stigmasterol (12) [29], 7-keto- $\beta$-sitosterol (13) [30,31], and 7-keto-stigmasterol (14) [32] 


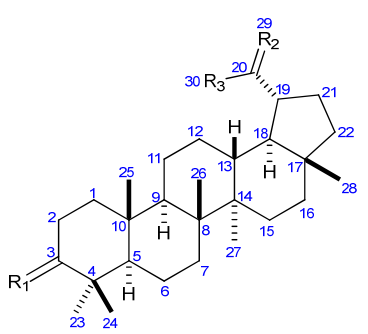

$1 \mathrm{R}_{1}=\alpha-\mathrm{H}, \beta-\mathrm{OH}, \mathrm{R}_{2}=\mathrm{CH}_{2}, \mathrm{R}_{3}=\mathrm{CH}_{3}$ $2 \mathrm{R}_{1}=\alpha-\mathrm{H}, \beta-\mathrm{OH}, \mathrm{R}_{2}=\mathrm{O}, \mathrm{R}_{3}=\mathrm{CH}_{3}$ $3 \mathrm{R}_{1}=\mathrm{O}, 1,2 \Delta, \mathrm{R}_{2}=\mathrm{CH}_{2}, \mathrm{R}_{3}=\mathrm{CH}_{3}$ $4 \mathrm{R}_{1}=\alpha-\mathrm{H}, \beta-\mathrm{OH}, \mathrm{R}_{2}=\mathrm{CH}_{2}, \mathrm{R}_{3}=\mathrm{CH}_{2} \mathrm{OH}$ $5 \mathrm{R}_{1}=$ caffeoyl, $\mathrm{R}_{2}=\mathrm{CH}_{2}, \mathrm{R}_{3}=\mathrm{CH}_{3}$ $6 \mathrm{R}_{1}=$ caffeoyl, $\mathrm{R}_{2}=\mathrm{CH}_{2}, \mathrm{R}_{3}=\mathrm{CH}_{2} \mathrm{OH}$ $7 \mathrm{R}_{1}=$ caffeoyl, $\mathrm{R}_{2}=\mathrm{CH}_{2}, \mathrm{R}_{3}=\mathrm{CHO}$ $8 \mathrm{R}_{1}=\alpha-\mathrm{H}, \beta-\mathrm{OH}, \mathrm{R}_{2}=\mathrm{O}, \mathrm{R}_{3}=\mathrm{OH}$

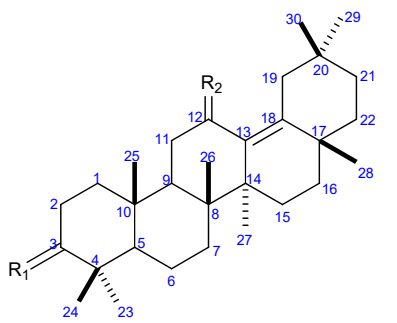

$15 \mathrm{R}_{1}=\mathrm{O}, \mathrm{R}_{2}=\mathrm{H}_{2}$ $16 \mathrm{R}_{1}=\alpha-\mathrm{H}, \beta-\mathrm{OH}, \mathrm{R}_{2}=\mathrm{H}_{2}$ $17 \mathrm{R}_{1}=\alpha-\mathrm{H}, \beta-\mathrm{OH}, \mathrm{R}_{2}=\mathrm{O}$

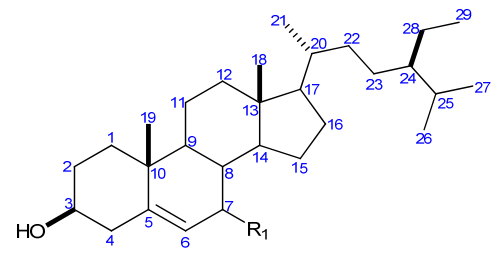

$9 \mathrm{R}_{1}=\mathrm{H}$

$10 \mathrm{R}_{1}=\mathrm{H},{ }^{22,23} \Delta$

$11 \mathrm{R}_{1}=\mathrm{OH}$

$12 \mathrm{R}_{1}=\mathrm{OH},{ }^{22,23} \Delta$

$13 \mathrm{R}_{1}=\mathrm{O}$

$14 \mathrm{R}_{1}=\mathrm{O},{ }^{22,23} \Delta$<smiles>CC[C@@]12C(=CC(=O)C3C1(C)CCC1C(C)(C)[C@@H](O)CC[C@]13C)C1CC(C)(C)CCC12C</smiles>

18

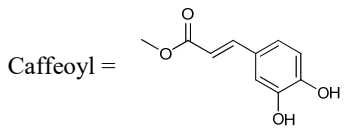

Figure 1. Structures of compounds (1-18) isolated from the aerial parts of Dobera glabra.

Compound 7 was obtained as a pale yellow amorphous solid. Based on the highresolution electron ionization mass spectrometry (HREIMS) evidence, the molecular formula of this compound was determined to be $\mathrm{C}_{39} \mathrm{H}_{54} \mathrm{O}_{5}$, derived from the quasi-molecular ion peak $\left(\mathrm{m} / \mathrm{z} 603.4048[\mathrm{M}+\mathrm{H}]^{+}\right)$, implying thirteen degrees of unsaturation. The infra-red (IR) spectrum of 7 included absorption bands at 3481, 1705, and $1688 \mathrm{~cm}^{-1}$, which were assigned to the $\mathrm{OH}$, conjugated $\mathrm{CO}$ ester, and aldehydic $\mathrm{C}=\mathrm{O}$ groups, respectively; the ultraviolet (UV) spectrum of 7 included absorption bands at $\lambda_{\max }=224,246,298$, and $330 \mathrm{~nm}$.

The ${ }^{13} \mathrm{C}$ NMR spectrum of compound 7 (Table 1), with the aid of the Distortionless Enhancement of Polarization Transfer using a 135 degree decoupler pulse (DEPT-135) and ${ }^{1} \mathrm{H}-{ }^{13} \mathrm{C}$ heteronuclear single quantum coherence (HSQC) experiments, was comprised of the resonance signals of 39 carbons, which were identified as six methyls, 11 methylenes (ten aliphatic and one vinylic), 12 methines (five aliphatic, one O-bearing at $\delta_{C} 81.5$, two olefinic at $\delta_{C} 115.8$ and 145.2, three aromatic at $\delta_{C} 114.4,115.5$ and 122.4, and one aldehydic at $\delta_{C} 196.0$ ), and 10 quaternary carbon atoms (five aliphatic carbons, one vinylic carbon at $\delta_{C} 157.5$, three aromatic carbons at $\delta_{C} 127.3,144.4$, and 146.9 , and one carbonyl carbon at $\delta_{C} 168.3$ ). Moreover, the ${ }^{1} \mathrm{H}$ NMR spectrum (Table 1) of 7 comprised one characteristic aldehyde proton signal at $\delta_{H} 9.65(\mathrm{~s})$, two deshielded exocyclic methylene protons at $\delta_{H} 6.48$ and $6.11\left(1 \mathrm{H}\right.$ each, brs), one O-bearing methine proton at $\delta_{H} 4.72(\mathrm{t}, J=8.1)$, and six tertiary methyl group protons at $\delta_{H} 0.96(\mathrm{~s}), 0.99(\mathrm{~s}), 1.01(\mathrm{~s}), 1.04(\mathrm{~s}), 1.06$ (s), and $1.14(\mathrm{~s})$. In addition, two $\mathrm{H}$-atom signals associated to a trans olefinic bond were observed at $\delta_{H}$ $6.39(\mathrm{~d}, J=15.5)$ and $7.70(\mathrm{~d}, J=15.5)$; these signals were accompanied by three aromatic signals assignable to a 1,3,4-trisubstitued phenyl ring at $\delta_{H} 7.02(\mathrm{~d}, J=7.5), 7.11(\mathrm{~d}, \mathrm{~J}=7.5)$, and 7.26 (brs), indicating the presence of a caffeoyl moiety [17]. The aforementioned data suggest that 7 is a pentacyclic triterpenoid caffeate. 
Table 1. ${ }^{1} \mathrm{H}(500 \mathrm{MHz})$ and ${ }^{13} \mathrm{C}$ NMR $(125 \mathrm{MHz})$ spectroscopic data of compounds 7 and 17 in $\mathrm{CDCl}_{3}$.

\begin{tabular}{|c|c|c|c|c|}
\hline \multirow{2}{*}{ No. } & \multicolumn{2}{|c|}{7} & \multicolumn{2}{|c|}{17} \\
\hline & $\delta_{\mathrm{C}}$ & $\delta_{\mathbf{H}}$ & $\delta_{\mathrm{C}}$ & $\delta_{\mathbf{H}}$ \\
\hline 1 & 38.4 & $1.78, \mathrm{~m}$ & 39.5 & $\begin{array}{l}1.62, \mathrm{~m} \\
1.01, \mathrm{~m}\end{array}$ \\
\hline 2 & 23.9 & $1.80, \mathrm{~m}$ & 27.8 & $1.61, \mathrm{~m}$ \\
\hline 3 & 81.5 & $4.72, \mathrm{t}(8.1)$ & 79.4 & $3.16, \mathrm{dd}(11.0,4.8)$ \\
\hline 4 & 38.1 & - & 39.9 & - \\
\hline 5 & 55.4 & $0.92, \mathrm{~m}$ & 56.7 & $0.82, \mathrm{~m}$ \\
\hline 6 & 18.3 & $\begin{array}{l}1.65, \mathrm{~m} \\
1.53, \mathrm{~m}\end{array}$ & 19.4 & $\begin{array}{l}1.67, \mathrm{~m} \\
1.52, \mathrm{~m}\end{array}$ \\
\hline 7 & 34.3 & $1.52, \mathrm{~m}$ & 35.0 & $1.52, \mathrm{~m}$ \\
\hline 8 & 40.9 & - & 42.0 & - \\
\hline 9 & 50.2 & $1.36, \mathrm{~m}$ & 51.6 & $1.74, \mathrm{~m}$ \\
\hline 10 & 37.1 & - & 38.4 & - \\
\hline 11 & 21.0 & $\begin{array}{l}1.47, \mathrm{~m} \\
1.30, \mathrm{~m}\end{array}$ & 41.5 & $2.30, \mathrm{~m}$ \\
\hline 12 & 27.7 & $1.14, \mathrm{~m}$ & 209.9 & - \\
\hline 13 & 37.8 & 1.07 & 140.6 & - \\
\hline 14 & 42.8 & - & 46.6 & - \\
\hline 15 & 27.4 & $1.82, \mathrm{~m}$ & 26.2 & $\begin{array}{l}1.89, \mathrm{~m} \\
1.12, \mathrm{~m}\end{array}$ \\
\hline 16 & 35.4 & $\begin{array}{l}1.65, \mathrm{~m} \\
1.57, \mathrm{~m}\end{array}$ & 36.9 & $1.40, \mathrm{~m}$ \\
\hline 17 & 43.4 & - & 36.2 & - \\
\hline 18 & 50.2 & $1.36, \mathrm{~m}$ & 149.6 & - \\
\hline 19 & 37.8 & $1.77, \mathrm{~m}$ & 40.5 & $1.67, \mathrm{~d}(12.7)$ \\
\hline 20 & 157.5 & - & 34.7 & - \\
\hline 21 & 29.8 & $1.40, \mathrm{~m}$ & 36.4 & $\begin{array}{l}1.60, \mathrm{~m} \\
1.21, \mathrm{~m}\end{array}$ \\
\hline 22 & 40.0 & $\begin{array}{l}1.58, \mathrm{~m} \\
1.52, \mathrm{~m}\end{array}$ & 40.1 & $1.46, \mathrm{~m}$ \\
\hline 23 & 28.1 & $1.01, \mathrm{~s}$ & 28.6 & $0.99, \mathrm{~s}$ \\
\hline 24 & 16.8 & $1.04, \mathrm{~s}$ & 16.2 & $0.79, \mathrm{~s}$ \\
\hline 25 & 16.2 & $0.99, \mathrm{~s}$ & 16.4 & $0.95, \mathrm{~s}$ \\
\hline 26 & 16.0 & $1.14, \mathrm{~s}$ & 17.5 & $1.06, \mathrm{~s}$ \\
\hline 27 & 14.5 & $1.06, \mathrm{~s}$ & 22.1 & $0.97, \mathrm{~s}$ \\
\hline 28 & 17.9 & $0.96, \mathrm{~s}$ & 23.7 & $1.11, \mathrm{~s}$ \\
\hline 29 & 134.2 & $\begin{array}{l}6.48, \text { brs } \\
6.11 \text {, brs }\end{array}$ & 24.9 & 0.87, brs \\
\hline 30 & 196.0 & $9.65, \mathrm{~s}$ & 32.7 & $0.93, \mathrm{~s}$ \\
\hline $1^{\prime}$ & 168.3 & - & & \\
\hline $2^{\prime}$ & 115.8 & $6.39, \mathrm{~d}(15.5)$ & & \\
\hline $3^{\prime}$ & 145.2 & $7.70, \mathrm{~d}(15.5)$ & & \\
\hline $4^{\prime}$ & 127.3 & - & & \\
\hline $5^{\prime}$ & 114.4 & 7.26, brs & & \\
\hline $6^{\prime}$ & 144.4 & - & & \\
\hline $7^{\prime}$ & 146.9 & - & & \\
\hline $8^{\prime}$ & 115.5 & $7.02, \mathrm{~d}(7.5)$ & & \\
\hline $9^{\prime}$ & 122.4 & 7.11, d (7.5) & & \\
\hline
\end{tabular}

The assignments of the signals due to the methyl groups and the remaining proton and carbon signals were performed through ${ }^{1} \mathrm{H}-{ }^{1} \mathrm{H}$ COSY and ${ }^{1} \mathrm{H}-{ }^{13} \mathrm{C}$ HMBC experiments Ultimately, these data enabled us to conclude the gross structure of 7 to be that of a lupanetype triterpenoid caffeate (Figure 2) $[17,21,22]$. Key ${ }^{1} \mathrm{H}-{ }^{13} \mathrm{C}$ HMBC cross-peaks were observed between $\mathrm{H}_{3}-23, \mathrm{H}_{3}-24\left(\delta_{H} 1.01,1.04\right.$, respectively) and C-3, C-5; $\mathrm{H}_{3}-25\left(\delta_{H} 0.99\right)$ and $\mathrm{C}-5, \mathrm{C}-9 ; \mathrm{H}_{3}-26\left(\delta_{H} 1.14\right)$ and $\mathrm{C}-9 ; \mathrm{H}_{3}-27\left(\delta_{H} 1.06\right)$ and $\mathrm{C}-8, \mathrm{C}-13, \mathrm{C}-14$, and C-15; $\mathrm{H}_{3}-28\left(\delta_{H} 0.96\right)$ and $\mathrm{C}-16, \mathrm{C}-17$, and $\mathrm{C}-22$; and $\mathrm{H}_{2}-29 / \mathrm{H}-30$ and $\mathrm{C}-20$. Based on the abovedetailed observations, the planar structure of the triterpenoid moiety of 7 was identified to 
be $3 \beta$-hydroxylup-20(29)-en-30-al. The caffeoyl unit is proposed to be linked to the C-3 of the triterpenoid moiety, given that the NMR resonance of $\mathrm{H}-3$ was downfield-shifted to $\delta_{H}$ $4.72(\mathrm{t}, J=8.1)$ in 7 with respect to compound $\mathbf{1}\left(\delta_{H} 3.16(\mathrm{dd}, J=8.1)\right)$, and the resonance of C-3 was downfield-shifted to $\delta_{C} 81.5$ in 7 compared to $\delta_{C} 79.04$ in 1 . This conclusion was ultimately confirmed by the observed HMBC correlation between H-3 and C-1' $\left(\delta_{C} 168.3\right)$. Furthermore, the aldehyde group proton $\left(\delta_{H} 9.65(\mathrm{~s})\right)$ was assigned at $\mathrm{C}-30$, as inferred via the ${ }^{2} J_{\mathrm{CH}} \mathrm{HMBC}$ correlation between H-30 and C-20 $\left(\delta_{C} 157.5\right)$, as well as the ${ }^{3} J_{\mathrm{CH}} \mathrm{HMBC}$ correlation between vinylic protons $\mathrm{H}_{2}-29$ and $\mathrm{C}-30$. Accordingly, 7 was elucidated to be lup-20(29)-en-30-al 3 $\beta$-caffeate.
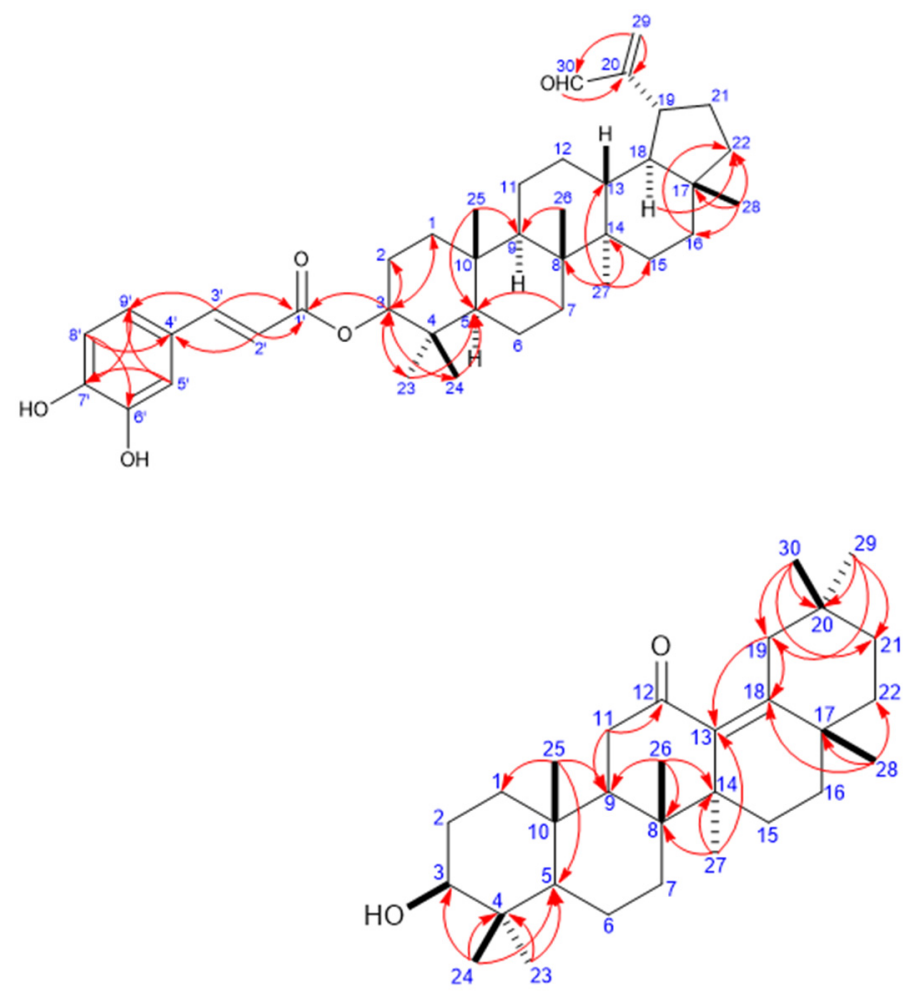

Figure 2. Key Heteronuclear multiple-bond correlation spectroscopy correlations $(\mathrm{H} \rightarrow \mathrm{C})$ in compounds 7 and 11.

Compound 17 was obtained as a white amorphous solid. Its molecular formula was determined to be $\mathrm{C}_{30} \mathrm{H}_{48} \mathrm{O}_{2}$, based on the HR-ESI-MS data $\left(\mathrm{m} / z 441.3733\left([\mathrm{M}+\mathrm{H}]^{+}\right.\right.$; calc. 441.3733), implying seven degrees of unsaturation. The IR spectrum of $\mathbf{1 7}$ included absorption bands at 3436 and $1663 \mathrm{~cm}^{-1}$, which were assigned to a hydroxyl group and a conjugated ketone, respectively.

The ${ }^{1} \mathrm{H}$ NMR spectrum of $\mathbf{1 7}$ included resonance signals due to one oxygenated methine at $\delta_{\mathrm{H}} 3.16(1 \mathrm{H}, \mathrm{dd}, J=11.0,4.8 \mathrm{~Hz}, \mathrm{H}-3)$, and eight methyl protons at $\delta_{\mathrm{H}} 0.79$ $(3 \mathrm{H}, \mathrm{s}, \mathrm{H}-24), 0.87$ (3H, s, H-29), 0.93 (3H, s, H-30), 0.95 (3H, s, H-25), 0.97 (3H, s, H-27), $0.99(3 \mathrm{H}, \mathrm{s}, \mathrm{H}-23), 1.06(3 \mathrm{H}, \mathrm{s}, \mathrm{H}-26)$, and $1.11(3 \mathrm{H}, \mathrm{s}, \mathrm{H}-28)$. The ${ }^{13} \mathrm{C}$ NMR spectrum of 17 was comprised of resonance signals due to 30 carbons, including a conjugated ketone carbonyl group at $\delta_{\mathrm{C}} 209.9$ (C-12), two olefinic carbons at $\delta_{\mathrm{C}} 140.6$ and 149.6 of four substituted double bonds, eight methyls at $\delta_{\mathrm{C}} 32.7$ (C-30), 28.6 (C-23), 24.9 (C-29), 23.7 (C-28), 22.1 (C-27), 17.5 (C-26), 16.4 (C-25), and 16.2 (C-24), three methines (two aliphatic and one O-bearing at $\delta_{C} 79.4$ ), ten methylenes, and six aliphatic quaternary carbons (Table 1). The above-mentioned spectroscopic data indicate that compound $\mathbf{1 7}$ is a pentacyclic triterpene.

The assignment of the signals of the methyl groups and the remaining of proton and carbon signals was performed through ${ }^{1} \mathrm{H}-{ }^{1} \mathrm{H}$ COSY and ${ }^{1} \mathrm{H}-{ }^{13} \mathrm{C}$ HMBC experiments; the data collected in this way indicated the gross structure of $\mathbf{1 7}$ to be that of an oleane- 
type triterpenoid [16] (Figure 2). Key HMBC correlations were observed between $\mathrm{H}_{3}-23$, $\mathrm{H}_{3}-24\left(\delta_{H} 0.99,0.79\right.$, respectively) and C-3 $\left(\delta_{C} 79.4\right), \mathrm{C}-5\left(\delta_{C} 56.7\right) ; \mathrm{H}_{3}-25\left(\delta_{H} 0.95\right)$ and C-1 $\left(\delta_{C} 39.5\right), \mathrm{C}-5\left(\delta_{C} 56.7\right)$, and $\mathrm{C}-9\left(\delta_{C} 51.6\right) ; \mathrm{H}_{3}-26\left(\delta_{H} 1.06\right)$ and $\mathrm{C}-8\left(\delta_{C} 42.0\right), \mathrm{C}-9\left(\delta_{C} 51.6\right)$, and $\mathrm{C}-14\left(\delta_{C} 46.6\right) ; \mathrm{H}_{3}-27\left(\delta_{H} 0.97\right)$ and $\mathrm{C}-8\left(\delta_{C} 42.0\right), \mathrm{C}-13\left(\delta_{C} 140.6\right), \mathrm{C}-14\left(\delta_{C} 46.6\right)$, and C$15\left(\delta_{C} 26.2\right) ; \mathrm{H}_{3}-28\left(\delta_{H} 1.11\right)$ and $\mathrm{C}-17\left(\delta_{C} 36.2\right), \mathrm{C}-18\left(\delta_{C} 149.6\right)$, and C-22 $\left(\delta_{C} 40.1\right)$; $\mathrm{H}_{3}-29\left(\delta_{H} 0.87\right) / \mathrm{H}_{3}-30\left(\delta_{H} 0.93\right)$ and C-19 $\left(\delta_{C} 40.5\right), \mathrm{C}-20\left(\delta_{C} 34.7\right)$, and C-21 $\left(\delta_{C} 36.4\right)$. Furthermore, a key ${ }^{2} J_{\mathrm{CH}} \mathrm{HMBC}$ correlation between $\mathrm{H}_{2}-11\left(\delta_{H} 2.30\right)$ and C-9/C-12 $\left(\delta_{C} 209.9\right)$, accompanied by a ${ }^{2} J_{\mathrm{CH}} \mathrm{HMBC}$ correlation from $\mathrm{H}_{2}-19\left(\delta_{H} 1.67\right)$ to $\mathrm{C}-18$, and a ${ }^{3} J_{\mathrm{CH}} \mathrm{HMBC}$ correlation from $\mathrm{H}_{2}-19 / \mathrm{H}_{3}-27$ and $\mathrm{C}-13$, and from $\mathrm{H}_{3}-28$ to $\mathrm{C}-18$ indicated the presence of a 12-oxo-olean 13(18)-ene system [24,33]. Based on the above observations, the structure of 17 was deduced to be that of 12 -oxo-olean-13(18)-en-3 $\beta$-ol (12-oxo- $\delta$-amyrin).

\subsection{Cytotoxic Activity}

The antitumor activities of the different fractions and isolated compounds were tested against different cancer cell lines (HCT-116, PC-3, and HepG-2). The data indicated that compound 11 showed broad-spectrum activity on three different cell lines. Interestingly, all of the extracts exhibited good $\left(\mathrm{CHCl}_{3}\right.$ extract) to moderate (n-hexane, butanol, and ethanol extracts) activity. On the other hand, most of the pure compounds (1-4, 8, and 9) displayed no activity, whereas compounds 5-7 and 13 displayed moderate activity (Table 2). Perhaps the higher activity of all of the extracts against the pure compounds was due to synergistic effect of all of the secondary metabolites in the whole extracts, rather than one compound. According to the obtained results (Table 2), the sterol nucleus, in general, exhibited stronger activity than that of lupane triterpene. For the sterol, the maximum activity was observed with the $7 \alpha$-enol system. The oxidation of the $7 \alpha$-hydroxy group to form the 7-enone system reduced the activity, while the activity of the lupane nucleus is improved by acylation with caffeic acid at $\mathrm{OH}-3[13,14]$.

Table 2. Cytotoxic activities of the different plant extract fractions and isolated compounds.

\begin{tabular}{|c|c|c|c|c|}
\hline Fractions/Compounds & $\begin{array}{c}\text { HCT-116 } \\
\text { IC }_{50}(\mu \mathrm{g} / \mathrm{mL})\end{array}$ & $\begin{array}{c}\text { PC-3 } \\
\mathrm{IC}_{50}(\mu \mathrm{g} / \mathrm{mL})\end{array}$ & $\begin{array}{c}\text { HepG-2 } \\
\mathrm{IC}_{50}(\mu \mathrm{g} / \mathrm{mL})\end{array}$ & $\begin{array}{c}\text { VERO-B } \\
\text { IC }_{50}(\mu \mathrm{g} / \mathrm{mL})\end{array}$ \\
\hline Hexane fraction & $24 \pm 0.34$ & $24 \pm 0.34$ & $24 \pm 0.34$ & $82 \pm 1.4$ \\
\hline $\mathrm{CHCl}_{3}$ fraction & $7.1 \pm 0.23$ & $7.1 \pm 0.23$ & $7.1 \pm 0.23$ & $80 \pm 0.2$ \\
\hline$n$-Butanol fraction & $16 \pm 1.31$ & $16 \pm 1.31$ & $16 \pm 1.31$ & $78 \pm 1.4$ \\
\hline Crude ethanolic extract of stems & $18 \pm 0.02$ & $18 \pm 0.02$ & $18 \pm 0.02$ & $86 \pm 0.5$ \\
\hline Crude ethanolic extract of leaves & $19 \pm 1.46$ & $19 \pm 1.46$ & $19 \pm 1.46$ & $80 \pm 1.4$ \\
\hline 1 & $>100$ & $>100$ & $>100$ & $>100$ \\
\hline 2 & $>100$ & $>100$ & $>100$ & $>100$ \\
\hline 3 & $>100$ & $>100$ & $>100$ & $>100$ \\
\hline 4 & $>100$ & $>100$ & $>100$ & $>100$ \\
\hline 5 & $59 \pm 0.45$ & $59 \pm 0.45$ & $59 \pm 0.45$ & $81 \pm 1.1$ \\
\hline 6 & $68 \pm 1.72$ & $68 \pm 1.72$ & $68 \pm 1.72$ & $68 \pm 0.3$ \\
\hline 7 & $62 \pm 1.42$ & $62 \pm 1.42$ & $62 \pm 1.42$ & $>100$ \\
\hline 8 & $>100$ & $>100$ & $>100$ & $>100$ \\
\hline 9 & $>100$ & $>100$ & $>100$ & $>100$ \\
\hline 11 & $8 \pm 1.02$ & $8 \pm 1.02$ & $8 \pm 1.02$ & $70 \pm 0.5$ \\
\hline 13 & $22.3 \pm 0.24$ & $22.3 \pm 0.24$ & $22.3 \pm 0.24$ & $64 \pm 1.1$ \\
\hline Cisplatin & $12.6 \pm 2$ & $5 \pm 0.45$ & $5 \pm 1.5$ & $11 \pm 1.3$ \\
\hline
\end{tabular}

In order to investigate the selectivity of the most active compounds for cancer cell lines, and to demonstrate that they had no cytotoxic effects on normal (non-cancerous) cells, viability and wound-healing assays were performed. Over $95 \%$ cell viability (in Vero cells) was obtained at a $70 \mu \mathrm{M}$ concentration of the most active compounds, so the biocompatibility was confirmed by conducting the wound-healing assay at either 35 or $70 \mu \mathrm{M}$ concentrations of each compound. The cells treated with compound $\mathbf{1 1}$ were able to heal the wound at a rate closer to that observed for untreated cells (Figure 3). These data indicated that 11, the 
most active compound, is not cytotoxic to normal cells, and that it is worth investigating further for use as a safe anticancer agent.

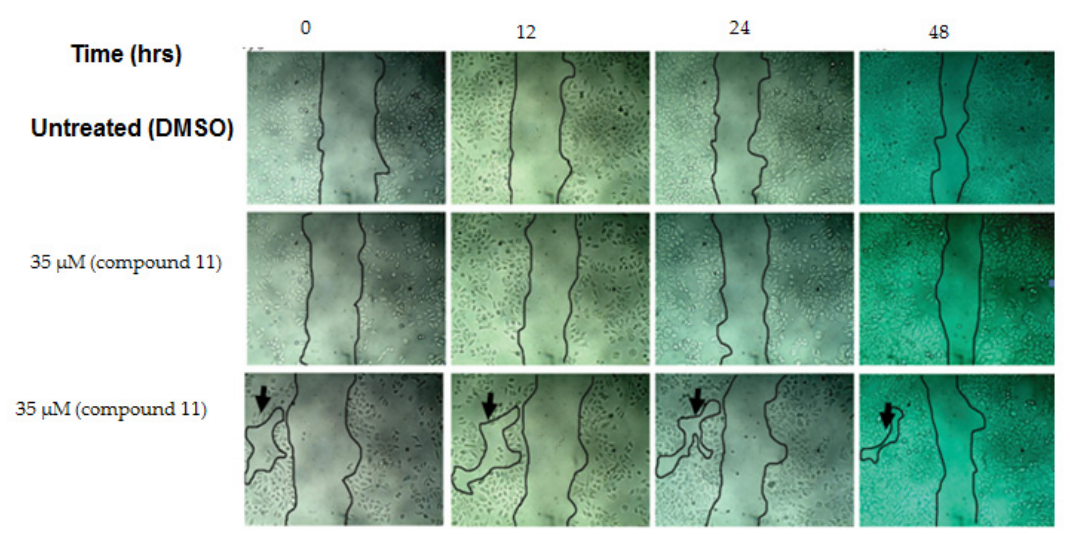

Figure 3. Effect of compound $\mathbf{1 1}$ on the wound healing of normal cells (Vero cell line). The cells were able to migrate in order to decrease the space between each other (black arrow), so that the wound size decreased after $48 \mathrm{~h}$ of incubation.

\subsection{Possible Cytotoxicity Mechanism of Compound $\mathbf{1 1}$}

The bioactivity of compound $\mathbf{1 1}$ was further investigated using phosphodiesterase, and this compound displayed an $80.2 \%$ inhibitory activity toward the mentioned enzyme in the used condition. Although high intracellular levels of cAMP have been reported to effectively inhibit the proliferation of cancer cells, compounds that cause cAMP levels to be elevated are not recommended as anticancer drugs, due to their high cytotoxicity [34-36].

All of the known phosphodiesterase inhibitors operate via three main types of interactions: interactions with metal ions mediated through water, $\mathrm{H}$-bond interactions with protein residues involved in nucleotide recognition, and, most importantly, interactions with the enzyme's hydrophobic residues; therefore, these interactions should guide the design of new classes of inhibitors [37].

Our research team, which consists of a multidisciplinary collection of international scientists, is developing more selective and effective anticancer agents than those that are available today, spurred on by the increasing need for safe and efficacious agents for cancer therapy. In this context, compound $\mathbf{1 1}$ proved to be an efficient and selective agent that is worth considering for further in vivo studies as a cancer treatment.

\section{Phosphodiestrase Inhibition Investigation}

Compound 11, which proved to be the most active and selective anticancer agent among all of the compounds tested in the present study, showed a remarkable inhibitory activity against phosphodiesterase I (PDE1), with an $80.2 \%$ inhibition of this enzyme at a $2 \mu \mathrm{M}$ concentration of the compound.

The in vitro assay revealed $\mathbf{1 1}$ to be a highly selective anticancer agent, with a noticeable cytotoxic activity against colorectal cancer (HCT-116), hepatocellular carcinoma (HepG-2), and prostate cancer (PC-3) cells compared to the commonly-used chemotherapeutic cisplatin drug.

Additionally, in the PDE1 inhibition tests, compound 11 exhibited a high cytotoxic activity against colorectal, prostate, liver cancers, with high selectivity. This high selectivity and promising activity against three aggressive cancer cell lines renders compound $\mathbf{1 1}$ a promising anticancer agent candidate. Therefore, the use of this compound in combination with other chemotherapeutic drugs should be carefully investigated as a way to explore the possibility of developing chemotherapeutic cancer treatments with increased efficacy and reduced undesired side-effects. 


\section{Materials and Methods}

\subsection{Instrumentation and Chemicals}

The Fourier-transform infrared (FT-IR) spectra were recorded on a Nicolet 5700 FT-IR Microscope spectrometer (FT-IR Microscope Transmission, company, Waltham, MA, USA). The optical rotations were measured using a Perkin-Elmer Model 341 LC polarimeter (PerkinElmer, MA, USA). The accurate mass determination was achieved with a JEOL JMS-700 High-Resolution Mass Spectrophotometer (JEOL USA Inc., Peabody, MA, USA) with a positive and negative mode. The NMR spectroscopy experiments were carried out using deuterated chloroform and an UltraShield Plus 500 (Bruker) spectrometer operating at $500 \mathrm{MHz}$ for ${ }^{1} \mathrm{H}$ and $125 \mathrm{MHz}$ for ${ }^{13} \mathrm{C}$ at the College of Pharmacy, Sattam Bin Abdulaziz University. The microplate reader used was a Coming Inc., NY, USA, ELISA BioTek $\mathrm{L} \times 800$ microplate. The thin layer chromatography (TLC) was performed on normal and reversed phase silica gel (Merck, Darmstadt, Germany) with a layer thickness of $250 \mu \mathrm{m}$ and a mean particle size of $10-12 \mu \mathrm{m}$, with different dimentions. $n$-hexane:EtOAc, $\mathrm{CHCl}_{3}: \mathrm{EtOAc}$ and $\mathrm{CHCl}_{3}: \mathrm{MeOH}$ were used for the normal phase TLC, while $\mathrm{H}_{2} \mathrm{O}: \mathrm{MeOH}(10: 90)$ was used for reversed phase RP-18 TLC. Additionally, the compounds were visualized by spraying the TLC plates with $15 \% \mathrm{H}_{2} \mathrm{SO}_{4}$ /ethanol, or with anisaldehyde-sulfuric acid, followed by heating. The column chromatography was carried out on silica gel (Merck $60 \mathrm{~A}$, 230-400 mesh ASTM, Darmstadt, Germany), while LiChrorep RP-18 (25-40 $\mu \mathrm{m})$ was used for the reversed phase column chromatography.

The centrifugal preparative TLC (CPTLC) was performed on a chromatotron instrument (Harrison Research, Palo Alto, California, CA, USA). Plates coated with 1 and $2 \mathrm{~mm}$ of silica gel 60, 0.04-0.06 mm were used. The reagents, chemicals, and solvents were of analytical grade, and they were purchased from Sigma-Aldrich, Loba Chemie Pvt. Ltd., and SD Fine Chem. Ltd. The water was doubly distilled before use [38,39].

\subsection{Plant Material}

The aerial parts of D. glabra were collected from the Shoqaiq in February 2013. The specimen of the plant was identified by Mohamed Yousef, Professor of Taxonomy at the Department of Pharmacognosy, College of Pharmacy, King Saud University. A voucher specimen No. 16,036 of D. glabra was deposited at the herbarium of the Pharmacognosy Department, College of Pharmacy, King Saud University, Kingdom of Saudi Arabia. The undesirable parts of plant material were removed. The aerial parts were dried in air-shade until they reached a constant weight, after which they were ground using a toothed mill, followed by sifting using suitable mesh in order to give a homogenous particle size powder for the subsequent efficient extraction.

\subsection{Extraction and Isolation}

The air-dried and powdered aerial parts of D. glabra (1200 g) were extracted by maceration with $96 \%$ ethanol. The extract thus obtained was evaporated in vacuo to yield a brownish residue $(28 \mathrm{~g})$, which was suspended in water and subsequently partitioned with $n$-hexane ( $3 \mathrm{~g})$, chloroform ( $4.5 \mathrm{~g})$, and $n$-butanol $(0.5 \mathrm{~g})$, in succession.

The $n$-hexane fraction was purified by chromatography over a silica gel column and eluted with $\mathrm{CHCl}_{3}$ :EtOAc mixtures of increasing polarity. On the basis of the TLC behavior, the appropriate fractions were combined in order to give seven main fractions $\left(\mathrm{H}_{1}-\mathrm{H}_{7}\right)$. The columns were monitored by examination under a UV lamp 254/366 nm, followed by spraying with $15 \% \mathrm{H}_{2} \mathrm{SO}_{4}$ in ethanol, followed by heating at $120{ }^{\circ} \mathrm{C}$. Fractions $\mathrm{H}_{1}-\mathrm{H}_{3}$ were eluted with $\mathrm{CHCl}_{3}: \mathrm{EtOAc}$ (98:2-95:5), and yielded compounds 1 (50.0 mg), 9 (54.0 mg), and $10(40.0 \mathrm{mg})$, after solvent treatment. Fraction $\mathrm{H}_{4}$ was purified by chromatography over an RP-18 column using $\mathrm{CH}_{3} \mathrm{CN}$ only as the eluent to afford compounds 2 (11.5 mg) and 3 (9.5 mg). Fraction $\mathrm{H}_{5}$ was eluted with $\mathrm{CHCl}_{3}: \mathrm{EtOAc}$ (98:2), and was further purified using a silica gel RP-18 column using methanol $(\mathrm{MeOH})$ as the eluent to afford compounds 15 (33.6 mg) and 16 (18.7 mg). Fraction $\mathrm{H}_{6}$ was subjected to a chromatotron (CPTL, silica gel $60 \mathrm{GF}_{254}, 1 \mathrm{~mm}$, solvent: $\mathrm{CHCl}_{3}:$ EtOAc (97:3)); this procedure yielded $31.0 \mathrm{mg}$ of compound 
13 and $12.7 \mathrm{mg}$ of compound 14. Fraction $\mathrm{H}_{7}$ was eluted with $\mathrm{CHCl}_{3}: \mathrm{EtOAc}$ (90:10), and was subjected to chromatography over a silica gel RP-18 column using $\mathrm{MeOH}$ only as the eluent, to yield compounds $\mathbf{1 1}(3.0 \mathrm{mg})$ and $\mathbf{1 2}(1.6 \mathrm{mg})$.

The $\mathrm{CHCl}_{3}$ fraction was purified by chromatography over a silica gel column, and was eluted with $\mathrm{CHCl}_{3}$ : $\mathrm{MeOH}$ mixtures of increasing polarity in order to yield five main fractions $\left(\mathrm{C}_{1}-\mathrm{C}_{5}\right)$. The crystallization of $\mathrm{C}_{1}$ in $\mathrm{CHCl}_{3}: \mathrm{MeOH}$ yielded compound 4 (13.0 mg); on the other hand, the filtrate of this fraction was subjected to CPTLC (silica gel $60 \mathrm{GF}_{254}$, $1 \mathrm{~mm}$, solvent: hexane:EtOAc (80:10)) to yield $5 \mathrm{mg}$ of compound 18. Fraction $\mathrm{C}_{2}$ was purified by CPTLC (silica gel $60 \mathrm{GF}_{254}, 1 \mathrm{~mm}$, solvent: hexane:EtOAc (70:30)) to give compound $8(8.7 \mathrm{mg})$.

Fractions $C_{3}$ and $C_{4}$ were re-chromatographed separately over a silica gel RP-18 column, using MeOH only as the eluent, to yield compounds 5 (14.0 mg), 6 (10.1 mg), and 7 (10.5 mg). The elution of the silica gel RP-18 column of fraction $\mathrm{C}_{5}$ with $\mathrm{H}_{2} \mathrm{O}: \mathrm{MeOH}(10: 90)$ afforded compound $\mathbf{1 7}(5.7 \mathrm{mg})$.

\subsection{Cytotoxic Activity}

\subsubsection{Cell Lines and Tested Compounds}

The cytotoxic activity of the different fractions and the isolated compounds was tested against different human cancer cells-that is, prostate carcinoma cells (PC-3), hepatocellular carcinoma cells (HepG-2), and colorectal cancer cell (HCT-116) - as well as against the African green monkey kidney cell line (Vero-B). The cell lines were obtained from the American Type Culture Collection. The cells were cultivated at $37^{\circ} \mathrm{C}$ and $10 \% \mathrm{CO}_{2}$ in Dulbecco's Modified Eagle Medium (Lonza, 12-604F) supplemented with 10\% fetal bovine serum (Lonza, Cat. No.14-801E), $100 \mathrm{IU} / \mathrm{mL}$ pencillin and $100 \mu \mathrm{g} / \mathrm{mL}$ streptomycin (Lonza, 17-602E). Cisplatin (cis-diamineplatinum (II) dichloride), obtained from sigma, was dissolved in $0.9 \%$ saline, then stored as an $8 \mathrm{mM}$ stock solution at $-20^{\circ} \mathrm{C}$ and used as the positive control.

The tested compounds were solubilized in dimethyl sulfoxide (DMSO) and stored at $-20{ }^{\circ} \mathrm{C}$. A $0.5 \%$ solution of crystal violet was prepared in $\mathrm{MeOH}$ and used to stain the viable cells [40-43]. Notably, crystal violet binds to proteins and DNA in adherent and viable cells, so this staining is indicative of the viability of the treated cells. The viability of the cells was quantified using the MTT reagent, which contains 3-(4,5-dimethylthiazol-2-yl)-2,5diphenyl tetrazolium bromide, and measures the activity of mitochondrial dehydrogenase in viable cells.

\subsubsection{Cell Cultures}

The cells were seeded in a 96-well plate as $5 \times 10^{4}$ cells $/ \mathrm{mL}(100 \mu \mathrm{L} /$ well). In total, $100 \mu \mathrm{L} /$ well of from the serial dilutions of the tested compounds and cisplatin $(100,30,10$, $3.3,1.1$, or $0.37 \mu \mathrm{M}$ ) were added to the plate after the overnight incubation of the cells at $37^{\circ} \mathrm{C}$ and $5 \% \mathrm{CO}_{2}$. DMSO was used as a control $(0.1 \%)$. The cells were incubated for $48 \mathrm{~h}$. Subsequently, $15 \mu \mathrm{l}$ MTT ( $5 \mathrm{mg} / \mathrm{mL}$ PBS, phosphate buffered saline) was added to each well, and the plate was incubated for another $4 \mathrm{~h}$. The formazan crystals were solubilized in $100 \mu \mathrm{L}$ acidified sodium dodecyl sulfate (SDS) solution (10\% SDS $/ 0.01 \mathrm{M} \mathrm{HCl})$. After $14 \mathrm{~h}$ of incubation at $37^{\circ} \mathrm{C}$ and $5 \% \mathrm{CO}_{2}$, the absorbance of the wells was measured at $570 \mathrm{~nm}$ using a Biotech plate reader. Each experiment was repeated three times, and the standard deviation was calculated $( \pm)$. The concentration that caused a $50 \%$ inhibition of the cell growth $\left(\mathrm{IC}_{50}\right)$ was calculated for each compound or fraction. The growth of the cells was monitored and the images were acquired using Gx microscopes (GXMGXD202 Inverted Microscope) (10x Eyepiece) after staining with crystal violet [44].

\subsection{Phosphodiestrase Inhibition Investigation}

The phosphodiesterase I inhibition assay was performed using snake venom according to a previously-reported method, with minute variations. Briefly, Tris- $\mathrm{HC} 1$ buffer $33 \mathrm{mM}$ at $\mathrm{pH} 8.8(97 \mu \mathrm{L}), 30 \mathrm{mM} \mathrm{Mg}$ acetate with an enzyme concentration of $0.742 \mu \mathrm{U}$ well- 1 , and 
$0.33 \mathrm{mM}$ bis-( $p$-nitrophenyl) phosphate (Sigma N-3002, $60 \mu \mathrm{L}$ ) as the substrate were taken. An EDTA solution characterized by an $\mathrm{IC}_{50} \pm$ SD value of $274 \pm 0.007 \mu \mathrm{M}$ was used as the positive control. After a pre-incubation period of $30 \mathrm{~min}$, the enzyme with the test samples was observed spectrophotometrically in order to detect its enzymatic activity on a microtitre plate reader at $37^{\circ} \mathrm{C}$. In particular, the rate at which the optical density of the sample changed (in $\mathrm{min}^{-1}$ ) was followed at $410 \mathrm{~nm}$, which is a wavelength absorbed by the $p$-nitrophenol released from $p$-nitrophenyl phosphate, a reaction known to be catalyzed by phosphodiesterase I. All of the assays were processed in triplicate [34-37].

\subsection{Wound-Healing Assay}

WI-38 cells were seeded in a 6-well plate at $20 \times 10^{4}$ cells per $\mathrm{ml}(2 \mathrm{~mL}$ in each well), which was incubated overnight at $37^{\circ} \mathrm{C}$ and $5 \% \mathrm{CO}_{2}$. During the second day, a scratch was created in each well with a p200 tip; the medium was then replaced with fresh medium containing either DMSO or different concentrations of the most active compounds. Images were recorded at different time points $(0,4,24$, and $48 \mathrm{~h})$ in order to monitor the wound closure. Subsequently, the cells were washed twice with ice-cold 1X PBS and fixed with ice-cold $\mathrm{MeOH}$ for $20 \mathrm{~min}$ at $4{ }^{\circ} \mathrm{C}$. The fixed cells were washed twice with 1X PBS and stained with $0.5 \%$ crystal violet for $30 \mathrm{~min}$. Any unreacted crystal violet was washed off with distilled $\mathrm{H}_{2} \mathrm{O}$ until no color was observed in the washing. The size of the wound was measured using Image J1.47 software [45].

\subsection{Analytical Data for Compound 7}

Compoud 7 is a pale yellow amorphous solid $(10.5 \mathrm{mg}) ;[\alpha]^{23} \mathrm{D}+17.4^{\circ}(c 0.5, \mathrm{MeOH})$; UV $\lambda_{\max } \mathrm{MeOH} n m(\log \varepsilon): 224$ (4.13), 246 (3.76), 298 (3.55), and 330 (3.82). IR (KBr) $v_{\max } 3481,2938,1705,1688,1617,1522,1447,1385,1267,1183,871 \mathrm{~cm}^{-1} ;{ }^{1} \mathrm{H}$ and ${ }^{13} \mathrm{C}$ NMR (see Tables 1 and 2); HR-ESI-MS [M + H] $]^{+} \mathrm{m} / z 603.4048$ (calculated for $\mathrm{C}_{39} \mathrm{H}_{54} \mathrm{O}_{5}, 603.4049$ ).

\subsection{Analytical Data for Compound $\mathbf{1 7}$}

Compound 17 is a white amorphous solid $(5.7 \mathrm{mg}) ;[\alpha]^{23} \mathrm{D}+31^{\circ}\left(c 0.8, \mathrm{CHCl}_{3}\right)$; UV $\lambda_{\max } \mathrm{MeOH} \mathrm{nm}(\log \varepsilon): 253$ (3.84). IR (KBr) $v_{\max }$ 3436, 2941, 2865, 1663, 1610, 1460, 1385, 1253, $1177 \mathrm{~cm}^{-1} ;{ }^{1} \mathrm{H}$ and ${ }^{13} \mathrm{C}$ NMR (see Tables 1 and 2); HR-ESI-MS [M + H] ${ }^{+} \mathrm{m} / z 4413.3733$ (calculated for $\mathrm{C}_{30} \mathrm{H}_{48} \mathrm{O}_{2}, 441.3733$ ).

\section{Conclusions}

Two compounds ( 7 and 17 ) were isolated for the first time from the aerial parts of $D$. glabra, and from a natural source. Additionally, a series of cytotoxic triterpenes and sterols, which were not previously known to be found in D. glabra, were also isolated from the mentioned plant parts. The structures of the new triterpenes were determined using a range of spectroscopic techniques, including high-resolution mass spectrometry. The different plant extracts and some of the isolated compounds were tested for their cytotoxic activity against colorectal cancer (HCT-116), hepatocellular carcinoma (HepG-2), and prostate cancer (PC-3) cell lines. The cytotoxic potency and selectivity of the bioactive compounds were investigated by the phosphodiestrase enzyme inhibition method. Compound $\mathbf{1 1}$ displayed a remarkable inhibitory activity against PDE1. The use of this compound in combination with other chemotherapeutic drugs should thus be investigated, in order to explore the possibility of producing chemotherapeutic cancer treatments characterized by increased efficacy and reduced undesired side effects.

Currently, a more rigorous in vivo study is underway, which is directed at obtaining more preclinical information, such as oral stability, bioavailability, and pharmacokinetic data, with the anticipation of better activity and a high safety margin.

Supplementary Materials: The following are available online at https:/ / www.mdpi.com/2223-774 7/10/1/119/s1, Figure S1: Structures of compounds (1-18) isolated from D. glabra.; Figures S2-S46 NMR spectral data (1D and 2D for compounds 1-8 and 13-18. 
Author Contributions: W.M.A.-M. isolated the compounds, interpreted the NMR data, revised the manuscript, and prepared the supplementary material. A.A.E.-G. and S.M.A.-M. isolated the compounds, wrote the manuscript, performed the investigation, assigned the spectral data, and designed the practical section. O.A.B. and M.S.A.-K. measured, interpreted, and assigned the NMR data, and helped in preparing/revising the manuscript. F.A.B. measured and discussed the biological activity section and revised the manuscript. A.J.A.-R. collected the plant, and wrote and revised the manuscript. H.Y.A. prepared and revised the manuscript. All authors have read and agreed to the published version of the manuscript.

Funding: This work was funded by the Deanship of Scientific Research at King Saud University through the Research Group Project No. RG 1437-021.

Acknowledgments: The authors would like to thank the Deanship of Scientific Research at King Saud University for funding the work through the Research Group Project No. RG 1437-021.

Conflicts of Interest: The authors declare no conflict of interest.

\section{References}

1. Vogt, K. A Field Worker's Guide to the Identification, Propagation and Uses of Common Trees and Shrubs of Dryland Sudan; SOS Sahel International: London, UK, 1996; p. 167.

2. Group, A.P. An update of the Angiosperm Phylogeny Group classification for the orders and families of flowering plants: APG III. Bot. J. Linn. Soc. 2009, 161, 105-121.

3. Al-Aklabi, A.; Al-Khulaidi, A.W.; Hussain, A.; Al-Sagheer, N. Main vegetation types and plant species diversity along an altitudinal gradient of Al-Baha region, Saudi Arabia. Saudi J. Biol. Sci. 2016, 23, 687-697. [CrossRef] [PubMed]

4. Aref, I.; El Atta, H.; Al Ghtani, A. Ecological study on Dobera glabra Forssk. At Jazan region in Saudi Arabia. J. Hortic. For. 2009, 1, 198-204.

5. Alfarhan, A.; Al-Turki, T.; Basahy, A. Flora of Jizan Region; King Abdulaziz City for Science and Technology (KACST): Riyadh, Saudi Arabia, 2005; Volume 1, p. 237.

6. Tsegaye, D.; Balehgn, M.; Gebrehiwot, K.; Haile, M.; Gebresamuel, G.; Aynekulu, E. The Role of 'Garsa' (Dobera glabra) for Household Food Security at Times of Food Shortage in Aba'ala Wereda, North Afar: Ecological Adaptation and Socio-Economic Value: A Study from Ethiopia; DCG: New York City, NY, USA, 2007.

7. Guinand, Y.; Lemessa, D. Wild Food Plants in Southern Ethiopia: Reflections on the Role of "Famine Foods" at a Time of Drought; UNDP-EUE Field Mission Report: Addis Ababa, Ethiopia, 2000.

8. Swaleh, A. Ethnoveterinary Medicine, in Ormaland-Kenya. Dissertation Submitted in Partial Fulfillment of the MSc; Centre for Tropical Veterinary Medicine (CTVM), University of Edinburgh: Edinburgh, UK, 1999.

9. Heywood, V.H.; Moore, D.M.; Richardson, I.B.K.; Sterrn, W.T. Salvadoraceae. Flowering Plants of the World, Croom Helm London E Sydney; Kew Science: Wakehust, UK, 2001.

10. Leslie, A.A.; Jarvis, P.G. Agroforesty practices in Somalia. For. Ecol. Manag. 1991, 45, 298-308. [CrossRef]

11. Barrow, E.G.C. Evaluating the effectiveness of participatory agroforestry extension programmes in a pastoral system, based on existing traditional values. A case study of the Turkana in Kenya. Agroforesty Syst. 1991, 14, 1-21. [CrossRef]

12. Elkhateeb, A.; Abdel Latif, R.R.; Marzouk, M.M.; Hussein, S.R.; Kassem, M.E.S.; Khalil, W.K.B.; El-Ansari, M.A. Flavonoid constituents of Dobera glabra leaves: Amelioration impact against $\mathrm{CCl}_{4}$-induced changes in the genetic materials in male rats. Pharm. Biol. 2017, 55, 139-145. [CrossRef]

13. Wang, W.-S.; Gao, K.; Wang, C.M.; Jia, Z.-J. Cytotoxic triterpenes from Ligulariopsis shichuana. Pharmazie 2003, 58, 148-150. [CrossRef]

14. Wu, S.-B.; Bao, Q.-Y.; Wang, W.-X.; Zhao, Y.; Xia, G.; Zhao, Z.; Zeng, H.; Hu, J.-F. Cytotoxic Triterpenoids and Steroids from the Bark of Melia azedarach. Planta Med. 2011, 77, 922-928. [CrossRef]

15. Reynolds, W.F.; McLean, S.; Poplawski, J.; Enriquez, R.G.; Escobar, L.I.; Leon, I. Total assignment of carbon-13 and proton spectra of three isomeric triterpenol derivatives by 2D NMR: An investigation of the potential utility of proton chemical shifts in structural investigations of complex natural products. Tetrahedron 1986, 42, 3419-3428. [CrossRef]

16. Mahato, S.B.; Kundu, A.P. ${ }^{13}$ C NMR Spectra of pentacyclic triterpenoids-A compilation and some salient features. Phytochemistry 1994, 37, 1517-1575. [CrossRef]

17. Fuchino, H.; Satoh, T.; Tanaka, N. Chemical evaluation of Betula species in Japan. I. Constituents of Betula ermanii. Chem. Pharm. Bull. 1995, 43, 1937-1942. [CrossRef]

18. Koul, S.; Razdan, T.K.; Andotra, C.S.; Kalla, A.K.; Koul, S.; Taneja, S.C.; Dhar, K.L. Koelpinin-A, B and C- three triterpenoids from Koelpinia linearis. Phytochemistry 2000, 53, 305-309. [CrossRef]

19. Puapairoj, P.; Naengchomnong, W.; Kijjoa, A.; Pinto, M.M.; Pedro, M.; Nascimento, M.S.J.; Silva, A.M.S.; Herz, W. Cytotoxic activity of lupane-type triterpenes from Glochidion sphaerogynum and Glochidion eriocarpum two of which induce apoptosis. Planta Med. 2005, 71, 208-213. [CrossRef] [PubMed] 
20. Betancor, C.; Freire, R.; Gonzalez, A.G.; Salazar, J.A.; Pascard, C.; Prange, T. Three triterpenes and other terpenoids from Catha cassinoides. Phytochemistry 1980, 19, 1989-1993. [CrossRef]

21. Alvarenga, N.; Ferro, E.A. A new lupane caffeoyl ester from Hippocratea volubilis. Fitoterapia 2000, 71, 719-721. [CrossRef]

22. Ying, Y.-M.; Li, C.-Y.; Chen, Y.; Xiang, J.-G.; Fang, L.; Yao, J.-B.; Wang, F.-S.; Wang, R.-W.; Shan, W.-G.; Zhan, Z.-J. Lupane- and Friedelane-type Triterpenoids from Celastrus stylosus. Chem. Biodivers. 2015, 12, 1222-1228. [CrossRef]

23. Kamble, S.M.; Patel, H.M.; Goyal, S.N.; Noolvi, M.N.; Umesh, B.; Mahajan, U.B.; Ojha, S.; Patil, C.R. In-Silico Evidence for Binding of Pentacyclic Triterpenoids to Keap1-Nrf2 Protein-Protein Binding Site. Comb. Chem. High Throughput Screen 2017, 20, 215-234. [CrossRef]

24. He, A.; Wang, M.; Hao, H.; Zhang, D.; Lee, K. Hepatoprotective triterpenes from Sedum sarmentosum. Phytochemistry 1998, 49, 2607-2610. [CrossRef]

25. Herath, H.M.T.B.; Athukoralage, P.S. Oleanane Triterpenoids from Gordonia ceylanica. Nat. Prod. Sci. 1998, 4, $253-256$.

26. Nyemb, J.N.; Magnibou, L.M.; Talla, E.; Tchinda, A.T.; Tchuenguem, R.T.; Henoumont, C.; Laurent, S.; Mbafor, J.T. Lipids constituents from Gardenia aqualla stapf \& hutch. Open Chem. 2018, 16, 371-376.

27. Pierre, L.L.; Moses, M.N. Isolation and Characterisation of Stigmasterol and $\beta$-Sitosterol from Odontonema strictum (Acanthaceae). J. Innov. Pharm. Biol. Sci. 2015, 2, 88-96.

28. Tasyriq, M.; Najmuldeen, I.A.; In, L.L.; Mohamad, K.; Awang, K.; Hasima, N. $7 \alpha$-Hydroxy- $\beta$-Sitosterol from Chisocheton tomentosus Induces apoptosis via dysregulation of cellular Bax/Bcl-2 ratio and cell cycle arrest by downregulating ERK1/2 activation. Evid. Based Complement. Alternat. Med. 2012, 2012, 765316. [CrossRef] [PubMed]

29. Achenbach, H.; Benirschke, G. Joannesialactone and other compounds from Joannesia princeps. Phytochemistry 1997, 45, 149-157. [CrossRef]

30. Della Greca, M.; Monaco, P.; Previtera, L. Studies on aquaticplants. Part XVI. Stigmasterols from Typha latifolia. J. Nat. Prod. 1990, 53, 1430-1435. [CrossRef]

31. Pettit, G.R.; Numata, A.; Cragg, G.M.; Herald, D.L.; Takada, T.; Iwamoto, C.; Riesen, R.; Schmidt, J.M.; Doubek, D.L.; Goswami, A. Isolation and structures of schleicherastatins 1-7 and schleicheols 1 and 2 from the teak forest medicinal tree Schleichera oleosa. J. Nat. Prod. 2000, 63, 72-78. [CrossRef] [PubMed]

32. Shu, Y.; Jones, S.R.; Kinney, W.A.; Selinsky, B.S. The synthesis of spermine analogs of the shark aminosterol squalamine. Steroids 2002, 67, 291-304. [CrossRef]

33. Tanaka, R.; Matsunaga, S. Triterpene constituents from Euphorbia Supina. Phytochemistry 1988, 27, 3579-3584. [CrossRef]

34. Hirsh, L.; Dantes, A.; Suh, B.S.; Yoshida, Y.; Hosokawa, K.; Tajima, K.; Kotsuji, F.; Merimsky, O.; Amsterdam, A. Phosphodiesterase inhibitors as anti-cancer drugs. Biochem. Pharmacol. 2004, 68, 981-988. [CrossRef]

35. Lugnier, C. Cyclic nucleotide phosphodiesterase (PDE) superfamily: A new target for the development of specific therapeutic agents. Pharmacol. Ther. 2006, 109, 366-398. [CrossRef]

36. Bischoff, E. Potency, selectivity, and consequences of non-selectivity of PDE inhibition. Int. J. Impot. Res. 2004, 16 (Suppl. S1), S11S14. [CrossRef]

37. Card, G.L.; England, B.P.; Suzuki, Y.; Fong, D.; Powell, B.; Lee, B.; Luu, C.; Tabrizizad, M.; Gillette, S.; Ibrahim, P.N.; et al. Structural basis for the activity of drugs that inhibit phosphodiesterases. Structure 2004, 12, 2233-2247. [CrossRef] [PubMed]

38. Muhammad, I.; Samoylenko, V.; Machumi, F.; Zakia, M.A.; Mohammed, R.; Hetta, M.H.; Gillum, V. Preparation and application of reversed phase Chromatorotor for the isolation of natural products by centrifugal preparative chromatography. Nat. Prod. Commun. 2013, 8, 311-314. [PubMed]

39. Kulkarni, N.; Mandhanya, M.; Jain, D.K. Centrifugal thin layer chromatography. Asian J. Pharm. Life Sci. 2011, 1, $294-300$.

40. Mohamed, N.H.; Liu, M.; Abdel-Mageed, W.M.; Alwahibi, L.H.; Dai, H.; Ismail, M.A.; Badr, G.; Quinn, R.J.; Liu, X.; Zhang, L.; et al. Cytotoxic cardenolides from the latex of Calotropis procera. Bioorg. Med. Chem. Lett. 2015, 25, 4615-4620. [CrossRef]

41. Feoktistova, M.; Geserick, P.; Leverkus, M. Crystal violet assay for determining viability of cultured cells. Cold Spring Harb. Protoc. 2016, 2016, pdb.prot087379. [CrossRef]

42. El-Gamal, A.A.; Al-Massarani, S.M.; Shaala, L.A.; Alahdald, A.M.; Al-Said, M.S.; Ashour, A.E.; Kumar, A.; Abdel-Kader, M.S.; Abdel-Mageed, W.M.; Youssef, D.T. Cytotoxic compounds from the Saudi Red Sea Sponge Xestospongia testudinaria. Mar. Drugs 2016, 14, 82. [CrossRef]

43. El-Gamal, A.A.; Al-Massarani, S.M.; Abdel-Mageed, W.M.; El-Shaibany, A.; Al-Mahbashi, H.M.; Basudan, O.A.; Badria, F.A.; Al-Said, M.S.; Abdel-Kader, M.S. Prenylated flavonoids from Commiphora opobalsamum stem bark. Phytochemistry 2017, 141, 80-85. [CrossRef]

44. El-Naggar, M.H.; Mira, A.; Bar, F.M.A.; Shimizu, K.; Amer, M.M.; Badria, F.A. Synthesis, docking, cytotoxicity, and LTA 4 H inhibitory activity of new gingerol derivatives as potential colorectal cancer therapy. Bioorg. Med. Chem. 2017, 25, 1277-1285. [CrossRef]

45. Lipton, A.; Klinger, I.; Paul, D.; Holley, R.W. Migration of mouse 3 T3 fibroblasts in response to a serum factor. Proc. Natl. Acad. Sci. USA 1971, 68, 2799-2801. [CrossRef] 